\title{
The quest for new tools to preserve rural heritage landscapes
}

\author{
Serge Schmitz \\ Laurent Bruckmann \\ Université de Liège. UR SPHERES. Laplec \\ s.schmitz@uliege.be \\ laurent.bruckmann@uliege.be
}

Received: March 2019

Accepted: December 2019

Published: April 2020

\begin{abstract}
This article aims to assess the tool of "grand site paysager" through its first implementation in Wallonia in order to reflect on tools that can preserve rural heritage landscapes. We seek to define the classification logic for this site and its relevance to the diversity of values and activities of site users. The "grand site" tool aims to preserve heritage landscapes of an intermediate scale, between the reserves of a few hectares and the national parks of several thousand hectares, but this tool has several weaknesses. Indeed, the multiple recreational uses seem to oppose the arguments for classification. Moreover, farming is neglected. However, we suggest that recreational value should be acknowledged as a community heritage.

Keywords: rural landscape; heritage; protection tools; Grand Site; Boucle de l'Ourthe; Belgium
\end{abstract}

Resum. La recerca de nous instruments per a la protecció dels paisatges patrimonials rurals

L'article vol avaluar l'instrument Grand Site Paysager mitjançant l'anàlisi de la seva implantació a Valònia per reflexionar sobre si aquestes eines poden ser útils per preservar els paisatges del patrimoni rural. L'objectiu és cercar la lògica que va conduir a la classificació del lloc i la seva importància per a la diversitat d'activitats i usuaris que rep. La categoria Grand Site pretén protegir el patrimoni paisatgístic a escala intermèdia, entre la reserva natural d'algunes hectàrees i el parc nacional de milers d'hectàrees. L'instrument té moltes deficiències. Els diversos usos recreatius semblen estar en oposició amb els arguments emprats per a la seva protecció i, també, sembla haver-se deixat de banda la funció agrícola. Tanmateix, segons l'opinió dels autors, cal reconèixer el valor recreatiu com a patrimoni comú.

Paraules clau: paisatges rurals; patrimoni; instruments de protecció; Grand Site; Boucle de l'Ourthe; Bèlgica 
Resumen. La buisqueda de nuevos instrumentos para la protección de los paisajes patrimoniales rurales

El artículo tiene como objetivo evaluar la herramienta Grand Site Paysager a partir del análisis de su primera implementación en Valonia a fin de reflexionar sobre el interés de estos instrumentos para preservar los paisajes del patrimonio rural. El objetivo es buscar la lógica que condujo a la clasificación de este lugar y su importancia para la diversidad de actividades y usuarios que recibe. La herramienta Grand Site pretende proteger los patrimonios paisajísticos a escala intermedia, entre la reserva natural de algunas hectáreas y el parque nacional de miles de hectáreas. El instrumento tiene muchas deficiencias. Los múltiples usos recreativos parecen oponerse a los argumentos empleados para su clasificación; asimismo, se ha dejado de lado la función agrícola. No obstante, según los autores, hay que reconocer el valor recreativo como patrimonio común.

Palabras clave: paisajes rurales; patrimonio; instrumentos de protección; Grand Site; Boucle de l'Ourthe; Bélgica

\section{Résumé. La quête de nouveaux outils pour protéger les paysages patrimoniaux ruraux}

L'article vise à analyser l'outil « Grand Site Paysager » au niveau de sa première implémentation en Wallonie afin de mener une réflexion sur les outils pour encadrer l'évolution des paysages ruraux patrimoniaux. Nous chercherons la logique qui a conduit à la classification de ce site et sa pertinence par rapport à la diversité des activités et des valeurs des usagers. L'outil " grand site " vise à protéger les paysages patrimoniaux d'échelle intermédiaire entre la réserve naturelle de quelques hectares et le parc national de plusieurs milliers d'hectares. Il présente cependant de nombreuses faiblesses. En effet, les multiples usages récréatifs semblent en opposition avec les arguments avancés pour sa classification et la fonction agricole est négligée. Nous suggérons cependant que la valeur récréative soit reconnue comme patrimoine commun.

Mots-clés: paysages ruraux; patrimoine; outils de protection; Grand Site; Boucle de l'Ourthe; Belgique

\section{Summary}
1. Introduction
5. Perception of the users
2. Theoretical considerations
6. Discussions and conclusions
3. Methodology
Bibliographical references

4. History of the designation

\section{Introduction}

The interest in landscapes has been renewed in recent decades since the signing of the European Landscape Convention (Council of Europe, 2000) due to the growing demand for "green" tourism (Butzmann and Job, 2017) and the recognition of ecosystem services (Alcamo et al., 2003; Daniel et al., 2012). The European Landscape Convention states that landscape quality objecti- 
ves contribute to balanced economic, environmental and social development. Moreover, European landscape diversity is promoted as part of the European identity. This pursuit is, however, threatened by several processes, including the standardisation of building and farming methods (Van Hecke et al., 2010).

Different states have established, improved or confirmed protection statuses for their landscapes considered to be heritage sites (Gómez Mendoza, 2013; Martín Jiménez, 2016). However, in some cases, such as in southeast Europe, the focus is mainly on the natural component, while other countries aim to encompass the cultural heritage (Schmitz et al., 2014; Roth et al., 2018). This research focuses on rural heritage landscapes often shaped by decades of farming. However, the linear decline in the number of farmers in many European regions requires a focus on landscape preservation (Schmitz, 2002). However, tools are missing or are in a pilot phase. Natural parks are often considered a good level at which to develop landscape plans or charters because in most countries they target sustainable rural development with a focus on natural and cultural heritage. In Wallonia, Belgium, natural parks are defined as areas of high biological and geographical interest of at least 10,000 ha. Moreover, since 2008, natural parks should implement a landscape charter. However, in some cases, a more restrictive area requires special attention and interventions. Site classification could be another opportunity, but it mainly concerns a limited area and strongly restricts the possible uses. Some inspiration could also be taken from the Natura 2000 network, the British Areas of Outstanding Natural Beauty (Powell et al., 2002) or the Polish Landscape Parks (Majchrowska, 2011; Badora, 2014).

Despite the undisputed value of these protection statutes, their implementation could be perceived as likely to undermine economic development, particularly where tourism generates small revenue. Thus, in Quebec, this perception is largely responsible for the fact that more than 15 years after the establishment of the status, no humanised landscape has yet been created (Domon and Ruiz, 2015). Elsewhere, this protection status is often used as a label that allows the differentiation of a tourist destination (Bénos and Milian, 2013; Schmitz and Vanderheyden, 2018). In France, several landscapes are labelled "grand site". This quality label is awarded to tourist sites that are based on landscape features and where management is acting to prevent the loss of the sense of the place by overtourism (Duval and Gauchon, 2007). These sites may cover several tens of square kilometres, such as the Puy Mary in Auvergne or the Baie de Somme in Picardy.

This paper reflects on an attempt to create a new tool between site classification and the French "grand site". Currently, only one landscape is classified as a "grand site" in Wallonia, but the idea to develop the tool is supported by several stakeholders. The novelty lies in the size (474 ha), the term "grand site", the qualifier "paysager" according to the recently acknowledged landscape or scenic value (since 1998) and the number and diversity of the stakeholders.

Through the study of the first "grand site paysager" in Wallonia, we aim to assess this tool and its implementation. Although the question of the grounds 
to acknowledge the heritage quality of landscapes is already covered, including in Wallonia (Droeven et al., 2007), their care is less documented. Which activities can/should they accommodate? What are the limits for their use, including concerning tourism development? How is the preservation of heritage landscape structures reconciled with the evolution of economic systems that affect this structure?

After a short statement concerning heritage landscape protection, this paper presents the history and the reasons for the classification of the first "grand site" in Wallonia. The following section analyses the sense of place of the users of the site. An assessment of the new tool and its first implementation concludes this paper.

\section{Theoretical considerations}

According to the European Landscape Convention, a landscape is an area (composed of private properties) that is perceived by the community as a common heritage (Antrop, 2005; Martín Jiménez, 2016). The convention justifies the need to protect landscapes because of their heritage characteristics without specifying the criteria. This idea suggests that any landscape could be protected and seen as heritage. The term "heritage", which originally refers to a family heritage, has also become synonymous with collective inheritance by a semantic shift (Di Méo, 2007). In the framework of the European Landscape Convention, protecting the landscape means acting to preserve and maintain the significant or characteristic aspects of it. However, the idea of strict protection seems to contradict even the concept of a landscape as a complex, dynamic system that is under pressure from many biophysical and anthropogenic actors and factors.

A heritage landscape can be a landscape classified by scientists and experts who, on the basis of historical, ecological or other characteristics, see it as a remarkable expression of an anthropogenic system. A heritage landscape can also be a landscape mediated by artistic representations or simply recognised as an element of community identity (Mitchell and Buggey, 2000). Nevertheless, a landscape can be seen and appropriated from multiple perspectives (Antrop, 1989; Schmitz, 2004; Vanderheyden et al., 2014; Harvey and Waterton, 2015), and this difference in views may create conflicts.

For Di Méo (2007), the territoire and heritage are twins by both their material and ideal nature as well as by the need for appropriation by both the individual and the community. He emphasises that any areas of a territoire can become heritage. However, heritage landscape is not at the same scale as areas typically classified as heritage; at the scale of the landscape, the details are fading (Droeven et al., 2007).

The issue of the desired and desirable development of landscapes, including heritage landscapes, also arises in the literature. These land-use conflicts are largely based on the perception and the values that shape perception. In practice, conflicting visions may occur both in recognition of the heritage value 
and in implementing intervention plans. Lahaye (2007) suggested analysing these conflicts from the triple points of view of the cohabitation of uses, the values assigned to nature/heritage and the ways to enhance the protected site. Recognition as heritage may lead to gains in attractiveness and to corrupted landscape. Touristification has already been studied (e.g. Bellini and Pasquinelli, 2016) at the urban level but still lacks studies in rural areas. Vos and Klijn (2000) spoke of a tourist paradox because the development of tourist infrastructures can destroy the original qualities that led to the recognition as heritage. Considering agricultural landscapes, another issue is the decline in the number of farmers and the increasing mechanisation that could contribute to the disappearance of heritage structures (Kerkstra and Vrijlandt 1990; Woods, 2011). Finally, the issue of developing renewable energy projects in such landscapes is also a hot topic. Some people use heritage characteristics as a criterion of exclusion for renewable energy development (e.g. Lejeune and Feltz, 2008), while others point out that today's heritage landscapes can be the energy landscapes of yesterday (Pasqualetti, 2000; Frantal et al., 2018).

\section{Methodology}

This paper is based on the analysis of the first and only "grand site paysager" in Wallonia (Fig. 1). First, we analyse the history of the designation and underline the different stakeholders and the reasons for their involvement. Second, we assess the sense of place of the users and actors (Jorgensen and Stedman, 2001) answering questions such as: How do they represent this landscape in their everyday life? Do they recognise this place as part of their personal identity and history? Would they invest time and financial resources to protect this place? (Shamai, 1991; Schmitz, 2012). Third, we study their positions and motivations regarding heritage recognition and their actions pro or contra this recognition.

Among the questions that guide the analysis, we are particularly interested in the following:

- What is protected? What are the results of the protection?

- Who are the actors pro and contra? Where do they live?

- Who are the winners and losers of the classification as "grand site paysager"?

- What are the value systems in co-presence?

- What are the risks for protected landscapes and for the development of local communities?

The case study is based on a grey literature analysis, interviews with key respondents, an oral survey of a sample of passers-by and an analysis of comments on TripAdvisor.

We interviewed six key respondents (a municipal civil servant, a farmer, an active member of a neighbourhood committee, an officer from the Walloon heritage office, the head of the watershed office and an emeritus professor identified as key people by other interviewees). We asked the respondents the 
questions listed above and recorded the interviews to allow the two authors to analyse the content several times.

With the help of students, we interviewed 127 passers-by during six days from March to July 2018. Due to the size of the site, its multiple entrances and the large number of visitors during the entire year for different purposes, surveying the users was more than challenging. We had to conduct short interviews in different places for several days; we tried to stop the cyclists, but ultimately, we had to accept that our sample missed some categories of users. We surveyed the same number of men and women; 55\% of the interviewed passers-by lived near the site, $35 \%$ came from the urban agglomeration of Liège and 10\% came from areas farther away. The questionnaire contained a section to identify the passers-by (gender, age, postal code, length of residence in the neighbourhood), a section on the visits (number of visits, main activities, composition of the group, source of information), a section on the meaning of the place and the landscape, an open question about suggestions to improve the place and, finally, a list of 14 Likert items about the site. Each Likert item consisted of a short descriptive phrase that the respondents rated on a level of agreement (Likert, 1932). For this research, we opted for

Figure 1. Location of the study area

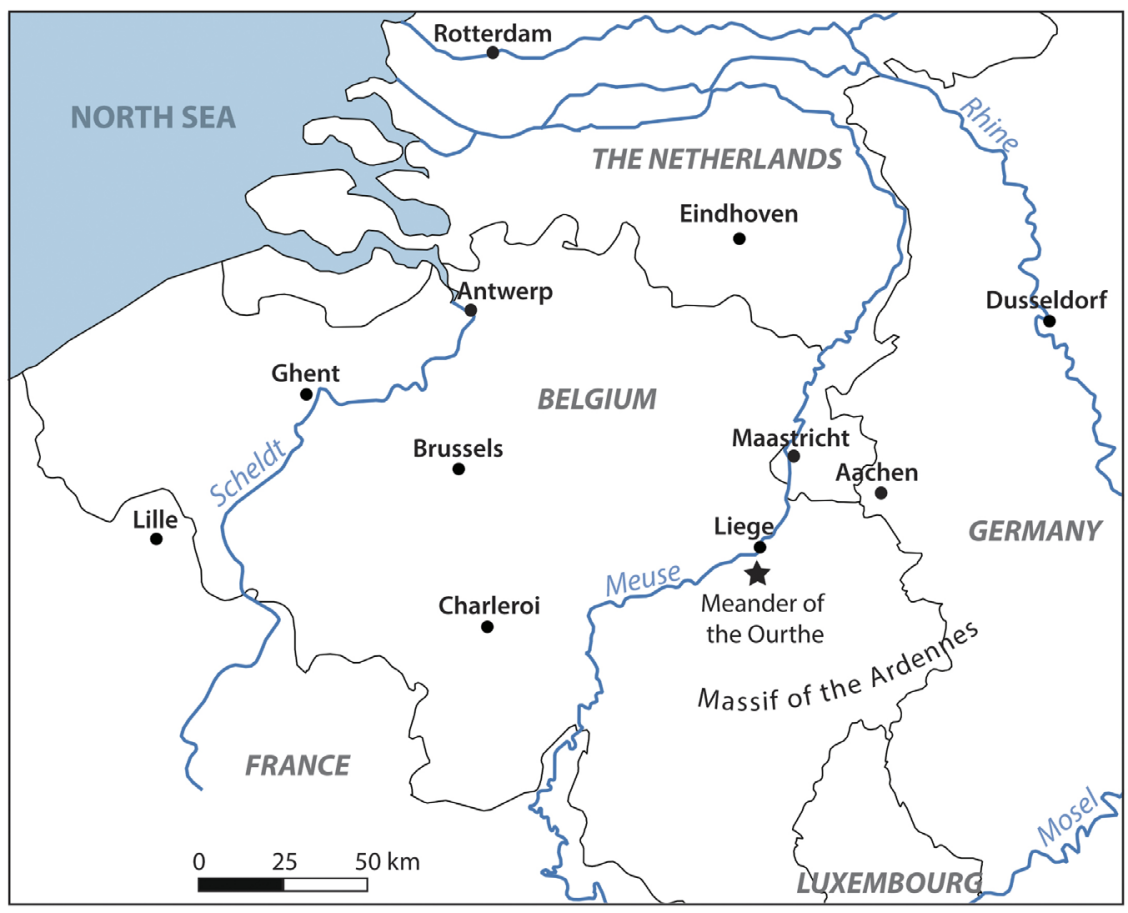

Source: Laplec2018 @. 
a four-level scale: totally disagree, somewhat disagree, somewhat agree, and totally agree.

To complete our sample, we analysed the comments posted on TripAdvisor about "La Roche aux Faucons". Previous researchers have noted the accuracy of TripAdvisor concerning hotels and restaurants (Miguéns et al., 2008; O'Connor, 2010; Lee et al., 2011), and we found a rich source of information concerning the experiences and perceptions of visitors of natural sites.

\section{History of the designation}

The Boucle de l'Ourthe at Neupré-Esneux is the first and only "grand site paysager" in Wallonia. This deep meander of the river Ourthe is covered with deciduous forest on steep slopes and agricultural land, mainly pastures, in the valley (Fig. 2). It encompasses two hamlets (100 \& 130 inh.) and three active family farms. Protected from the main road, the Boucle de l'Ourthe constitutes a landscape of high readability, seen as a coherent whole that stimulates imagination. It is an open space located $17 \mathrm{~km}$ from the city centre of Liège (450,000 inh.) next to the new campus (1976) of the university and the town of Esneux (3,000 inh.). The Boucle de l'Ourthe includes archaeological heritage such as the Farm of Rosière, the Castrum of Beaumont and the Meuse-Moselle Canal.

Since the end of the 19th century, several artists have frequented this loop of the Ourthe to appreciate its picturesque appearance. Intellectual "elites" met regularly in Ham (a hamlet located in the heart of the loop), especially in 1905 for the first organisation of "the tree festival". The history of the designation of the landscape site starts from the 1920s, with the work of the Association for the Safeguarding of the Ourthe loop. Active from 1924 to 1964, its members wanted to preserve the beauty and the silence of the site from pollution and

Figure 2. View of the Ourthe loop from La Roche aux Faucons overlook

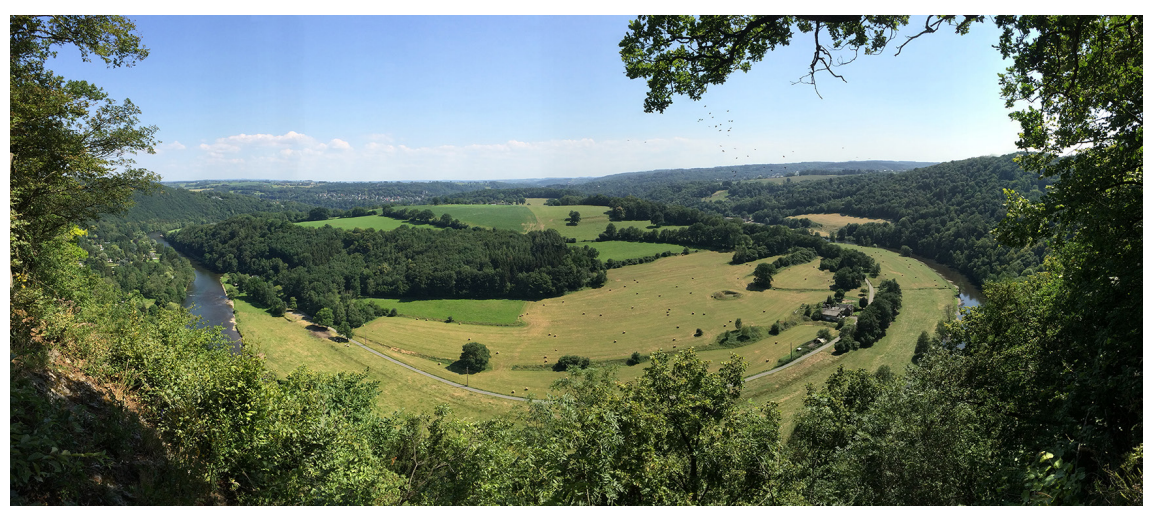

Source: Laplec2018 @. 
noise of the industrial city. ${ }^{1}$ They called for a classification of the site to contain urban and industrial sprawl. The members of the association stood up against the installation of a Lime Kiln (1924), the installation of a park of villas in the peninsula of Ham (1926), a dam at Esneux (1931), the installation of an observatory tower at the top of La Roche aux Faucons (1935), a road connecting the plateau to the valley (1941), and the paving of the towpath (APEE, 1980). In 1947, a protest created a legal precedent when the local authority denied the construction of a villa in Ham. This decision led to a ban on building on the peninsula. Over the period from 1924 to the beginning of the 1990s, several struggles and proposals of classification followed one another. Different elements were successively classified: the plateau of Beaumont in 1936, the slopes of this same plateau in 1948, the rock of La Roche aux Faucons and its slope in 1947 (36 ha), and the Château Lavaux in 1961 (Fig. 3). The association disappeared in 1964 after the death of the main actor. In 1975, a new association was founded. Once more, the objective was to fight against the transformation of the site, including new campsites, to preserve the nature and the aesthetic value of the loop. In 1980, a white paper detailed the characteristics of the site in favour of its protection. The paper includes contributions of an impressive panel of scientists from the neighbouring university (APEE, 1980). Following the publication of the book, the banks of the river were classified in 1981, the farm and the chapel of Saint-Donat were designated as monuments in 1989, and the hamlet of Ham was designated an architectural ensemble in 1991. In addition, as early as 1935, several proposals for the classification of the whole site were introduced. In 1993, the classified sites of the Ourthe loop were listed in the heritage of Wallonia, giving it national recognition, and it was renewed several times until 2011. This recognition of the overall value is a first step towards the creation of the grand site. In 2011, the municipalities of Esneux and Neupré implemented a soft mobility network in what is known as the Grand site de la Boucle de l'Ourthe to discover its natural and cultural heritage (Esneux and Neupré, 2011). Then, the regional authorities designated the site as a "grand site". The grand site includes six classified zones, which span a total of 95 ha, 1 ha of an architectural complex and 6 ha of a protection zone. Moreover, $40 \%$ of the area of the site (142 ha) is already listed in Natura $2000 .^{2}$ The aim of the classification is to promote coherence between relic areas such as the hamlet of Ham, the escarpments of Beaumont, and La Roche aux Faucons and their viewpoints.

The designation stems from multiple classifications in the same area for natural, landscape or architectural characteristics (Table 1). The role of civil society, residents and users of the site was crucial in the designation process.

1. Liège is known for its important metallurgical industry.

2. Natura 2000 is a network of nature protection areas in the European Union. It is based on the Special Areas of Conservation (SACs) and Special Protection Areas (SPAs) designated respectively under the Birds Directive (1979) and the Habitats Directive (1992). It covers $13 \%$ of Wallonia and some $18 \%$ of the land of the European Union (Natura 2000 Barometer, 2018). 
Figure 3. Map of the Ourthe meander and the characteristics of the classified sites

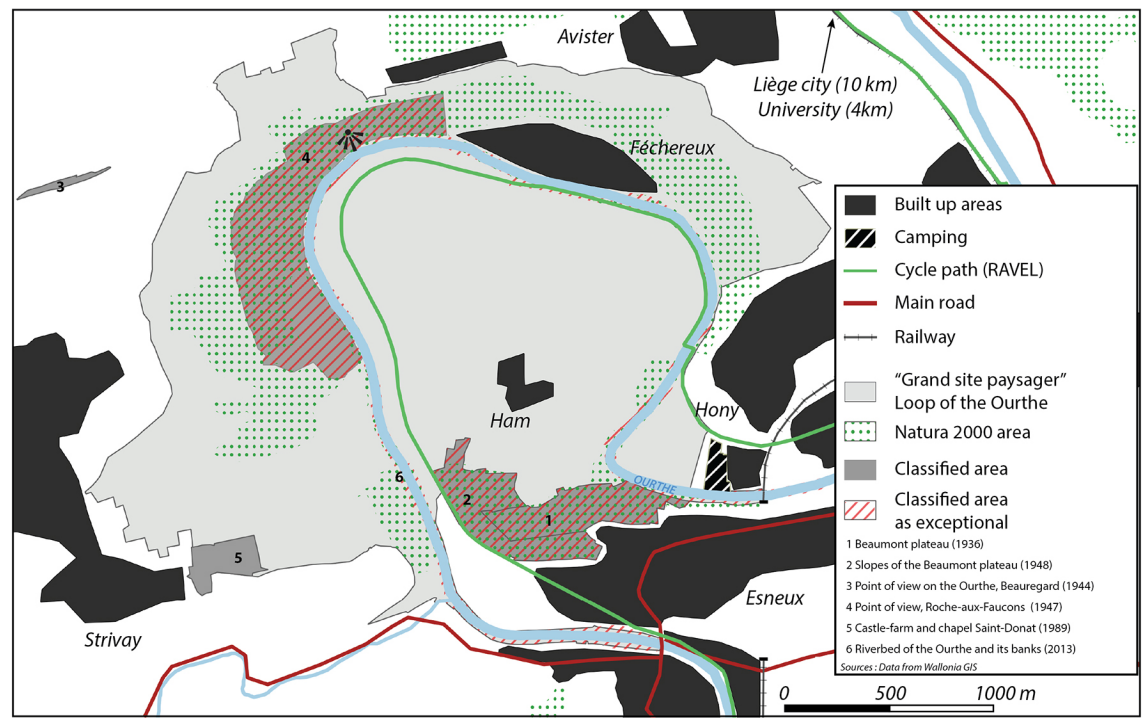

Source: Laplec2018 @.

The associations want to freeze and curb the transformation of the landscape to prevent anarchic urbanisation. If the first "grand site paysager" of Wallonia is associated with the countryside, its links with the city of Liège are important. Diverse authorities and citizens from the urban agglomeration supported the designation in regards to its beauty and the services that the site offers to the neighbouring agglomeration. The actors involved were not only artists, scientists (archaeologists, biologists, geographers, geologists, architects, etc.), and municipal and regional authorities, but also farmers and rangers; waterway and road agents; inhabitants of the site and inhabitants of neighbouring villages; tourists; organisations focussed on nature protection, heritage, and tourism development; and various sport associations. Except for some entrepreneurs and landowners who wanted to develop new settlements or campsites, most people are pleased with the protection of the site even if they are not aware of the legislation. The interviews with key respondents pointed out the role played by one or two leaders who were professors at the university and live in the neighbourhood. By acting to protect a site acknowledged as regionally important for its heritage and scenic viewpoints, they are protecting their own living environment. Interviewees mentioned, however, the reluctance of the inhabitants of Ham, who were afraid of the increasing number of walkers passing through the picturesque hamlet. They also reported that the few farmers were afraid of the consequence of the classification on their activities. Yet, although some restrictions appeared in the preparatory documents, the decree of classification of May 22, 2015 does not include a list of restrictions. 
Table 1. Classified areas and their characteristics in the Ourthe meander

\begin{tabular}{|c|c|c|c|c|}
\hline Classified area & Surface (ha) & $\begin{array}{c}\text { Year of } \\
\text { classification }\end{array}$ & $\begin{array}{l}\text { Type of } \\
\text { classification }\end{array}$ & $\begin{array}{l}\text { Heritage } \\
\text { classified as } \\
\text { exceptional }\end{array}$ \\
\hline Beaumont plateau & 10.60 & 1936 & Natural site & Yes \\
\hline $\begin{array}{l}\text { Viewpoint on the Ourthe, } \\
\text { Beauregard }\end{array}$ & 0.89 & 1944 & Natural site & \\
\hline $\begin{array}{l}\text { Viewpoint, La Roche aux } \\
\text { Faucons }\end{array}$ & 36.80 & 1947 & Natural site & Yes \\
\hline $\begin{array}{l}\text { Slopes of the Beaumont } \\
\text { plateau }\end{array}$ & 11.70 & 1948 & Natural site & Yes \\
\hline $\begin{array}{l}\text { Castle-farm and chapel } \\
\text { Saint-Donat }\end{array}$ & 4.34 & 1989 & $\begin{array}{l}\text { Architectural } \\
\text { site }\end{array}$ & \\
\hline $\begin{array}{l}\text { Riverbed of the Ourthe } \\
\text { and its banks }\end{array}$ & 33.40 & 2016 & Natural site & Yes \\
\hline $\begin{array}{l}\text { Valley of the Ourthe } \\
\text { between Comblain-au-Pont } \\
\text { and Angleur }\end{array}$ & 707.00 & 2002 & Natura 2000 & \\
\hline $\begin{array}{l}\text { Area already classified } \\
\text { inside the grand site }\end{array}$ & 239.00 & & & \\
\hline The Ourthe loop & 471.40 & 2015 & $\begin{array}{l}\text { "Grand site } \\
\text { paysager" }\end{array}$ & Yes \\
\hline
\end{tabular}

Source: APEE (1980); SPW (2012); SPW (2016).

\section{Perception of the users}

Most of the interviewees walked alone, in a small group or with a dog (Fig. 4). The others were cyclists, joggers, fishers, river bathers (even if doing so is prohibited for safety reasons), wildlife observers, picnickers or those who just stopped a while to admire the view from La Roche aux Faucons. The activities depend on the location, and indeed, few people know the rich diversity of these places and even fewer are aware of their historical value. For instance, on the one hand, the combination of this scenic landscape and the gentle cycling path constitutes a specific attraction not only for neighbours, but also for people living in Liège. On the other hand, the cycling sports fans want to climb the narrow road of La Roche aux Faucons like the professional cyclists of the World Cup race "Liège-Bastogne-Liège". Despite its classification, the site is essentially known via family and friends networks and is similar to a "secret we shared" by word of mouth. Others discovered the site by participating in activities, such as hiking different trails, or by watching the cycling race on TV. A total of $74 \%$ of surveyed people did not know that the loop is classified as a "grand site paysager".

Most people are attracted to this place because of the calm environment and the landscape (Fig. 5). It is a kind of holiday twenty minutes from the city and an ideal place to walk and bike. The surveys show an equal number 
Figure 4. Different assets of the Ourthe loop
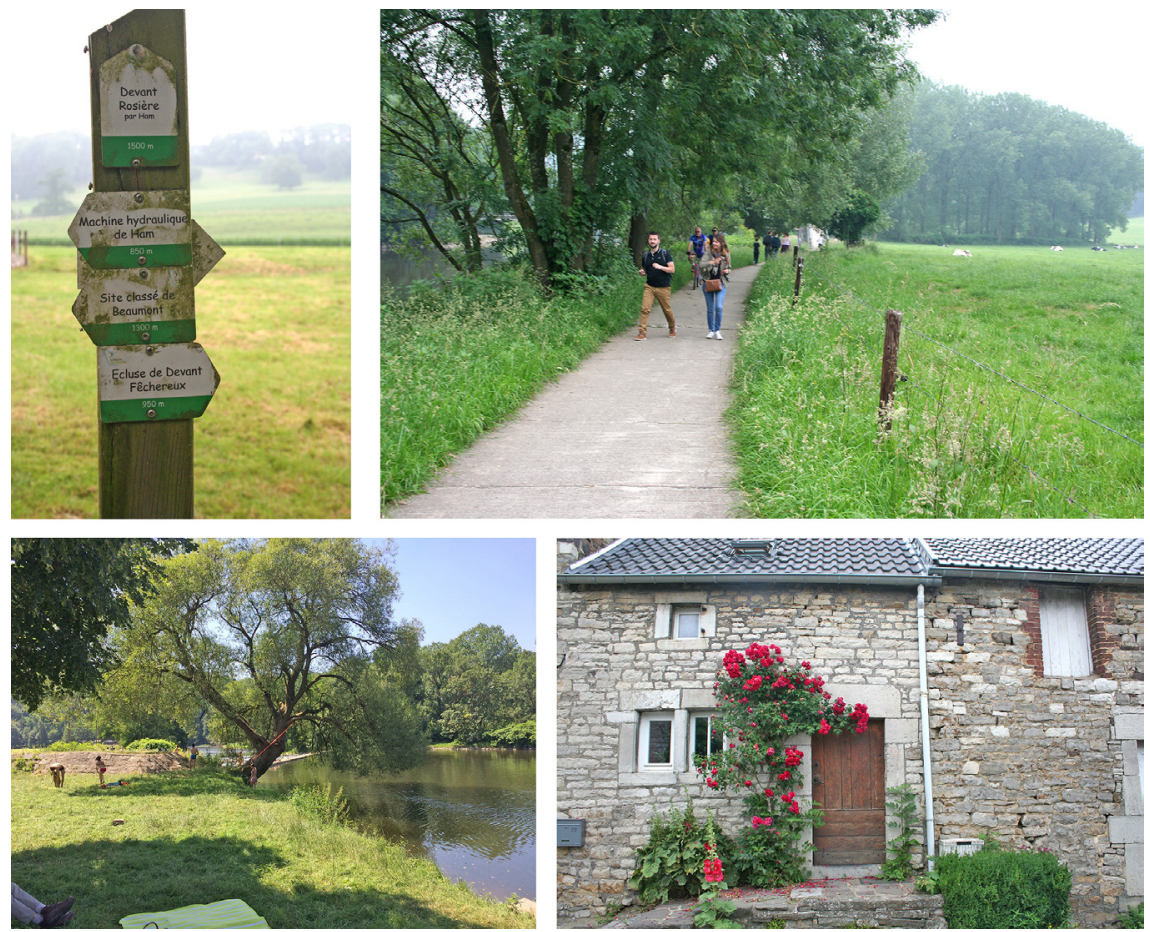

Source: Laplec2018 ๑.

of users who totally agreed (46\%) and those who rather agreed (46\%) that the Ourthe loop is one of the most beautiful landscapes in the region (Fig. 6). This finding suggests that the appeal of the landscape is more a construction depending both on the scale of references used to assess the landscape and the meaning given to the places (Schmitz and Vanderheyden, 2016). Passers-by were also somewhat sceptical about the great biodiversity of the site: only a quarter totally agreed on the great biodiversity, and most of them (57\%) stated that the historical heritage is poorly highlighted. They also expressed concerns about waste management. They were also pleased to be informed that the site is classified as a "grand site paysager". However, the opinions about specific rules for farmers and the construction or installation of hotels and pubs differ. While $37 \%$ of the passers-by pointed out the lack of restaurants and cafés on the site, $47 \%$ seem satisfied with the offerings that can be found in the neighbouring towns. Most of the respondents (75\%) rejected the development of other leisure activities. Users do not want to have a conservation area or an amusement park but rather a managed natural and enjoyable landscape that is equipped for leisure activities. 
Figure 5. Elements of attraction to the Ourthe loop and elements of improvement for the site 30

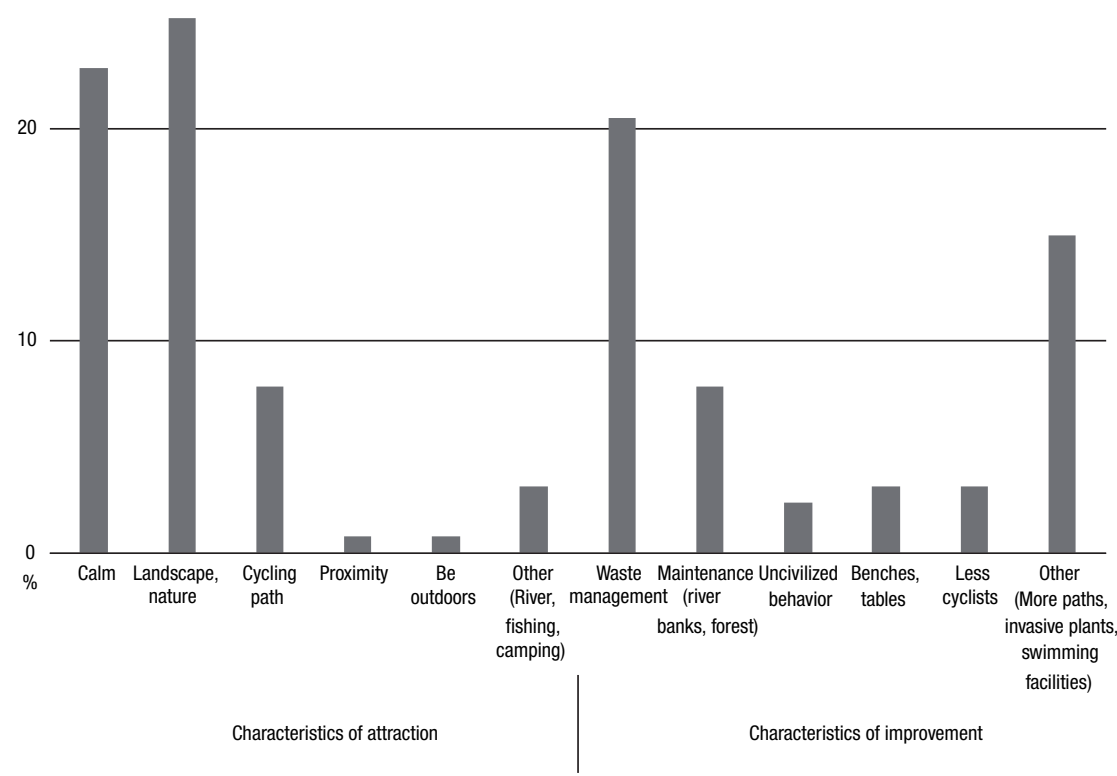

Source: Laplec2018 @.

The analysis of the 62 comments on TripAdvisor gives a similar distribution concerning the origin of the visitors. With a rating of 4.5, the comments pointed out the breath-taking view from La Roche aux Faucons, the numerous walking paths and the nature but also the presence of litter left by visitors.

We found this place beautiful. Beautiful nature, fine hiking, great cycling on the course of Liège-Bastogne-Liège. Tip: there are very few shops and so, be prepared and take food with you. (Dutch visitor, 2018, translated from Dutch)

Very pleasant place. Nice view on the Valley of the Ourthe. To be reached on foot or by bike. Sit a moment at the edge of the cliff and watch the flight of falcons. (Visitor from Brussels, 2013, translated from French)

We are far from the idea of cultural and natural heritage of national importance that was used to argue the classification. Indeed, the services provided by the site matter more than the heritage. If scientists want to protect the landscape to maintain vestiges of the past and geomorphological landforms, users claim that the place is part of their leisure and family history.

We used Lahaye's (2007) grid to analyse the dynamics of classification. For the Boucle de l'Ourthe, we listed some typical cohabitation conflicts among 
Figure 6. Respondents' opinions about the characteristics of the Ourthe meander

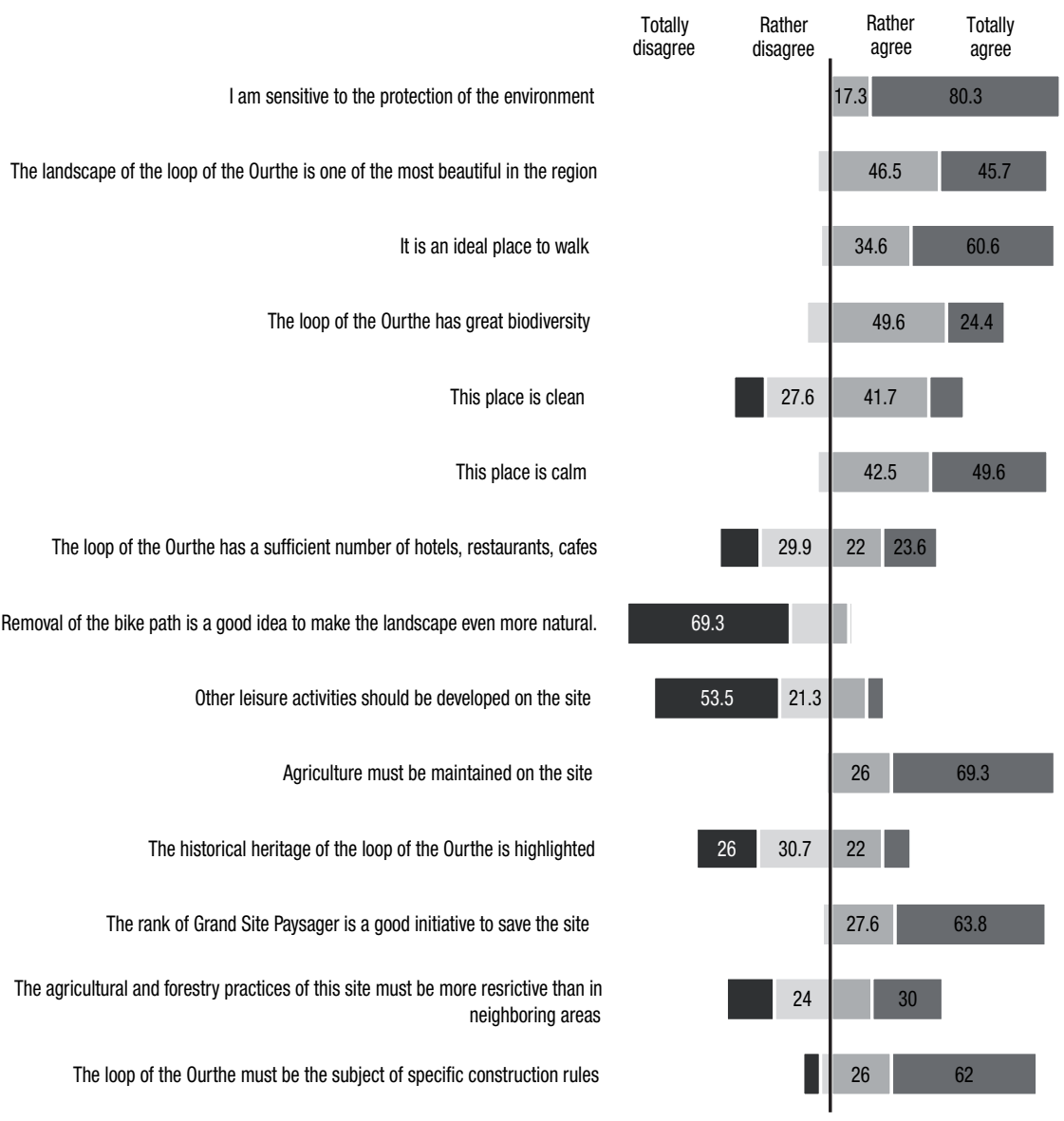

$\%$

Source: Laplec2018 @.

different sports (cyclists vs. walkers, kayakers vs. fishers, and horses vs. mountain bikes) and between farming and recreation, even if farmers have decided to accommodate tourists. One farmer opened a riding school, and another built a lodge for 10 tourists. The classification as a grand site has no impact on the work in the fields; however, it prescribes extra assessment before cutting down a tree or modifying a building. It should be mentioned that the fields located in Natura 2000 areas already face some limitations concerning soil amendment, changes in topography and the cutting down of trees. The farmer interviewed thinks that they will be the last farmers on the site because of the lack of prospects for farming. Family farms have to cope with the low prices 
of milk and meat on the market and with an increase in land prices due partly to financial speculation.

I do not think that there will be a farm here in the future. These are difficult times. (...) It will not be a farmer who will take over the farm. It will be horses like over there or someone who wants to have a large estate in the countryside, like a castle. (Farmer of the site, 2018, translated from French)

Nevertheless, some people face the difficulty of developing new activities, such as the inhabitant who would like to place a small turbine in the water to produce his own electricity. The perspective of the value assigned to nature is less problematic because most stakeholders have some respect for nature and want to enjoy it, and most of them want to keep the place secret and open only to locals. They have a hedonist and egocentric approach to nature and the site, including protection of the site, quite distant from the long lists of natural species that are supposed to be protected. When considering enhancing the protected site, a large majority of users want to keep it as it is.

\section{Discussions and conclusions}

For years, several viewpoints or relatively small sites were protected because of their scientific, historic or aesthetic value. In the last decade, marked by the adoption of the European Landscape Convention, attention has been paid to broader areas that constitute iconic landscapes. For the Ourthe loop, 474 ha are protected, that is, an intermediate scale between a classified site and a natural park. The classification as a grand site was a long process. Indeed, this classification comes in addition to a series of existing protection statuses. For the Ourthe loop, the inscription as a grand site transcends the archaeological, historical, aesthetic and scientific sites already protected.

As in many cases in Europe - for example, La Montagne St Victoire (VidalNaquet, 1992; Vlès and Hatt, 2015) and The Connemara (Brett, 1996) - the process to recognise the heritage characteristics started with aesthetic recognition by local and external artists, which was seconded by scientists. Then, hikers wanted to discover the landscape praised by artists, and finally, public authorities paid attention to the area. Therefore, people who are new to these landscapes initiated the recognition of their value before the residents and local authorities. Thus, recreational uses are at the root of the recognition process. Scientists intervene to provide information on the landscape system and to certify its interest, but tourism development motivates the authorities to obtain the label to both promote and protect the site. However, the two purposes are often irreconcilable. Meanwhile, this process is also the result of numerous fights to protect the landscape from different aggressive projects. The classification is then seen as a means to preserve the site.

In the case of the Boucle de l'Ourthe, few conflicts occurred because most of the people who know the site associate this landscape with a place of leisure 
and nature that should be unchanged or slightly adapted to welcome visitors. The neighbours benefit from a park and appealing scenery, urban people consider it a nice half-day destination to relax, and tourists enjoy this secret place of "wilderness". A distinction should be made between public properties that are mainly forests and private properties. Most residents do not face new constraints due to heritagisation because regulations to protect the sites existed before. There are few new bans. Farmers are more concerned from a twofold point of view: restrictions concerning their farming activities and interdictions to sell land to builders.

Users' motivations to visit the grand site are far from the arguments to classify it. If the argument to list the site as exceptional regional heritage is mainly based on scientific and historic values certified by experts from different academic disciplines, this landscape is first a place for recreation and resourcing that has to be protected against urban expansion and overtourism. The values associated with the site by users are first the natural environment and the quietness. Most people pay little attention to its biodiversity and cultural heritage. This finding underlines the idea that heritage landscape should be analysed not only from a historical or naturalistic perspective, but also include the uses and meanings given by people, as the European Landscape Convention clearly states. Recreation and tourism behaviours shape the interpretation of heritage and should be included as potential reasons for classification. Indeed, the feeling of quietness, the joy of being with friends along the river or on top of the hill, the experience of nature and the memories of the journey with family are also part of people's heritage, which is less tangible but shared by the community.

However, regional authorities are not prepared to incorporate recreation value as a reason to protect a site. The regional authorities also face barriers to allocating funds to protect the site because most of the budget is needed to maintain listed monuments. Concern about the future of farming is also neglected. Moreover, the classification of large open spaces is new, and regional authorities need to learn how to manage such landscapes.

The promotion of the site via the new label could increase the number of visitors, who are not all respectful of the environment. Concerning the Boucle de l'Ourthe, the impact of the new label on attractiveness is marginal because it is unknown and rarely used to attract tourists. If the different accommodations and municipalities mention the grand site on their webpage, the aim is not to attract tourists but to adduce evidence of the richness of the local heritage.

Finally, the designation as a "grand site" is more of a label to draw attention that this landscape is unique and risks corruption by a lack of caution concerning its transformation. This place shared by numerous users who enjoy it should provide numerous services for current and future inhabitants and visitors under the condition of being protected. This idea converges with the assumptions listed by Silva Pérez (2009): a landscape is seen as heritage to be protected if the scenery is owned collectively and if society acknowledges the tangible and intangible value of the landscape and wants to preserve these values for the next generations. 
The analysis of the first grand site of Wallonia shows that a new tool should be elaborated instead of classification of the site to protect scenic landscapes of intermediate size between a natural park and a listed cultural or natural site. Because the classification of "listed site" causes problems, it is an obstacle to new initiatives, constrains agricultural practices without supporting the survival of family farming, lacks funding and constitutes a poor label from a tourism point of view. The aim of this new tool should be to preserve and maintain the dominant landscape features. Moreover, this study pointed out that landscape heritage is not only a pattern of buildings and landforms, but also the way a community uses the environment and bears allegiance to the site. This is one of the challenges that must be addressed to bridge the gap between top-down policies and their social acceptance.

\section{Bibliographical references}

Alcamo, Joseph; Ash, Neville J.; Butler, Colin D.; Callicot, J. Baird; Capistrano, Doris; Carpenter, Stephen. R.;... and Zure, Monika B. (2003). Ecosystems and Human Well-Being: A Framework for Assessment. Washington, DC: Island Press.

Antrop, Marc (1989). Het landschap meervoudig bekeken. Kapellen: Pelckmans.

- (2005). "Why landscapes of the past are important for the future". Landscape and Urban Planning, 70 (1), 21-34. $<$ http://dx.doi.org/10.1016/j.landurbplan.2003.10.002>

APEE (Association pour la Protection de l'Environnement à Esneux) (1980). Livre blanc pour la sauvegarde du site de la Boucle de l'Ourthe à Esneux. Esneux: APEE.

Badora, Krzysztof (2014). "Spatial system of landscape protection in Poland". Dissertations of Cultural Landscapes Commission, 23, 73-88.

Bellini, Nicola and Pasquinelui, Cecilia (eds.) (2016). Tourism in the City: Towards an Integrative Agenda on Urban Tourism. New York: Springer.

BÉNos, Rémi and Milian, Johan (2013). "Conservation, valorisation, labellisation: la mise en patrimoine des hauts-lieux pyrénéens et les recompositions de l'action territorial". VertigO, Hors-série 16. $<$ https://doi.org/10.4000/vertigo.13631>

BRETT, David (1996). The Construction of Heritage. Cork: Cork University Press.

Frantál, Bohumil; Van der Horst, Dan; Martinát, Stanislav; Schmitz, Serge; Silva, Luis; Golobic, Mojca and Roтн, Michael (2018). "Spatial targeting, synergies and scale: Exploring the criteria of smart practices for siting renewable energy projects". Energy Policy, 120, 85-93. <http://dx.doi.org/10.1016/j.enpol.2018.05.031>

ButzmanN, Elias and Joв, Hubert (2017). "Developing a typology of sustainable protected area tourism products". Journal of Sustainable Tourism, 25 (12), 1736-1755. $<$ http://dx.doi.org/10.1080/09669582.2016.1206110>

Council of Europe (2000). European Landscape Convention. Firenze: European Treaty Series - No. 176.

Daniel, Terry C.; Muhar, Andreas; Arnberger, Anne; Aznar, Olivier; Boyd, James W.; Chan, Kai M.;... and von Der Dunk, Andreas (2012). "Contributions of cultural services to the ecosystem services agenda". Proceedings of the National Academy of Sciences, 109 (23), 8812-8819. $<$ https://doi.org/10.1073/pnas.1114773109> 
Di MÉo, Guy (2007). "Processus de patrimonialisation et construction des territories". In: Colloque "Patrimoine et industrie en Poitou-Charentes: connaître pour valoriser". Poitiers-Châtellerault: Geste éditions, 87-109.

Domon, Guy and Ruiz, Julie (2015). "La convention européenne des paysages: quels enseignements pour le Québec?”. VertigO. <http://dx.doi.org/10.4000/vertigo.15367>

Droeven, Emilie; Dubois, Catherine and Feltz, Claude (2007). "Paysages patrimoniaux en Wallonie (Belgique), analyse par approche des paysages témoins". Cahiers d'économie et sociologie rurales, 84, 216-243.

Duval, Mélanie and Gauchon, Christophe (2007). "Analyse critique d'une politique d'aménagement du territoire, les Opérations Grands Sites”. Annales de géographie, 654, 147-168. <http://dx.doi.org/10.3917/ag.654.0147>

Esneux and Neupré (2011). Le Grand Site de la Boucle de l'Ourthe. Esneux/Neupré: Les Collèges communaux d'Esneux et de Neupré. <http://www.escale-esneux.be/ Boucle_Ourthe.pdf>

Gómez Mendoza, Josefina (2013). "Del patrimonio-paisaje a los paisajes-patrimonio”. Documents d'Anàlisi Geogràfica, 59 (1), 5-20. $<$ https://doi.org/10.5565/rev/dag.48>

Harvey, David C. and Waterton, Emma (2015). "Editorial: Landscapes of heritage and heritage landscapes". Landscape Research, 40 (8), 905-910. <https://doi.org/10.1080/01426397.2015.1086563>

Jorgensen, Bradley S. and Stedman, Richard C. (2001). "Sense of place as an attitude: Lakeshore owners attitudes toward their properties". Journal of Environmental Psychology, 21 (3), 233-248. <http://dx.doi.org/10.1006/jevp.2001.0226>

Kerkstra, Klass and Vrijlandt, Peter (1990). "Landscape planning for industrial agriculture: A proposed framework for rural areas". Landscape and Urban Planning, $18(3-4), 275-287$. <http://dx.doi.org/10.1016/0169-2046(90)90015-T>

Lahaye, Nathalie (2007). "La dimension conflictuelle de la valorisation touristique d'un espace natuel protégé. Le cas du mont Orford”. Téreos, 26 (2), 46-52.

Lejeune, Philippe and Feltz, Claude (2008). "Development of a decision support system for setting up a wind energy policy across the Walloon Region (southern Belgium)". Renewable Energy, 33 (11), 2416-2422. <http://dx.doi.org/10.1016/j.renene.2008.02.011>

Lee, Hee Andy; Law, Rob and Murphy, Jamie (2011). "Helpful reviewers in TripAdvisor, an online travel community". Journal of Travel \& Tourism Marketing, 28 (7), 675-688. <http://dx.doi.org/10.1080/10548408.2011.611739>

Likert, Rensis (1932). "A technique for the measurement of attitudes". Archives of Psychology, 22, 5-55.

Majchrowska, Anna (2011). "The implementation of the European landscape convention in Poland". In: Jones, Michael and Stenseke, Marie (eds.). The European Landscape Convention. Dordrecht: Springer, 81-98. <http://dx.doi.org/10.1007/978-90-481-9932-7_5>

Martín Jiménez, María Isabel (2016). "Patrimonio y paisaje en España y Portugal. Del valor singular a la integración territorial”. Boletín de la Asociación de Geógrafos Españoles, 71, 347-374. 
Miguéns, Joana; Baggio, Rodolfo and Costa, Carlos (2008). "Social media and tourism destinations: TripAdvisor case study". Advances in Tourism Research, 26 (28), 1-6.

Mitchell, Nora and Buggey, Susan (2000). "Protected landscapes and cultural landscapes: Taking advantage of diverse approaches". The George Wright Society, 17 (1), 35-46.

O'Connor, Peter (2010). "Managing a hotel's image on TripAdvisor". Journal of Hospitality Marketing \& Management, 19 (7), 754-772. <https://doi.org/10.1080/19368623.2010.508007>

Pasqualetti, Martin J. (2000). "Morality, space, and the power of wind-energy landscapes”. Geographical Review, 90 (3), 381-394. <http://dx.doi.org/10.2307/3250859>

Powell, John; Selman, Paul and WragG, Amanda (2002). "Protected areas: reinforcing the virtuous circle". Planning Practice and Research, 17 (3), 279-295. <http://dx.doi.org/10.1080/026974502200005643>

Roth, Michael; Eiter, Sebastian; Röhner, Sina; Kruse, Alexsandra; Schmitz, Serge; Frantal, Bohumil; Centeri, Csaba; Frolova, Marina; Buchecker, Matthias; Storber, Dina; Karan, Isadoran and Van der Horst, Dan (2018). Renewable Energy and Landscape Quality. Berlin: Jovis.

Shamai, Shmuel (1991). "Sense of place: An empirical measurement". Geoforum, 22 (3), 347-358. <http://dx.doi.org/10.1016/0016-7185(91)90017-K>

Schmitz, Serge (2002). "Walloon Region: An agro-forestry landscape without farmers?”. Dela, 17, 174-182.

- (2004). "Le paysage invisible". In: Puech, Daniel and Honegger, Anne (eds.). L'évaluation du paysage : une utopie nécessaire? Montpellier: Publications de l'Université Paul Valéry, 27-33.

- (2012). "Un besoin de territoire à soi: quelques clés pour un aménagement des espaces communs". Belgeo, 1-2. <http://dx.doi.org/10.4000/belgeo.6627>

Schmitz, Serge and Vanderheyden, Vincent (2016). "Reflexive loops on scaling issues in landscape quality assessment". Land Use Policy, 53, 3-7. <http://dx.doi.org/10.1016/j.landusepol.2015.07.020>

- (2018). "Quels usages pour les paysages patrimoniaux? Réflexion à partir des grands sites paysages wallons”. In: PaüL, Valerià; Lois González, Rubén C.; TRIllo Santamaría, Juan Manuel and Haslam McKenzie, Fiona (eds.). Infinite Rural Systems in a Finite Planet: Bridging Gaps towards Sustainability. Santiago de Compostela: Universidade de Santiago de Compostela, 228-233.

Schmitz, Serge; Vanderheyden, Vincent; Teleuca, Alexandra and Patru-Stupariu, Ileana (2014). "Qu'entend-on par paysage de qualité? Résultats d'une enquête auprès d'experts roumains et wallons". In: Doo-Chul, Kim; Firmino, Ana Maria and YASUO, Ichikawa (eds.). Globalization and New Challenges of Agricultural and Rural Systems. Nagoya: Nagoya University Publisher, 35-44.

Silva PÉrez, Rocío (2009). "Agricultura, paisaje y patrimonio territorial. Los paisajes de la agricultura vistos como patrimonio". Boletín de la Asociación de Geógrafos Españoles, 49, 309-334.

SPW (Service Public de Wallonie) (2012). Réseau Natura 2000 en vigueur. Géoportail de la Wallonie. Namur: SPW. <https://geoportail.wallonie.be/catalogue/80a837d82c0b-4f77-b5d5-824e9780a4ae.html> 
SPW (Service Public de Wallonie) (2016). Patrimoine : Biens classés et zones de protection. Géoportail de la Wallonie. Namur: SPW. <http://geoportail.wallonie.be/ catalogue/01491630-78ce-49f3-b479-4b30dabc4c69.html>

Van Hecke, Etienne; Antrop, Marc; Schmitz, Serge; Van Eetvelde, Veerle and Sevenant, Marjanne (2010). Paysages, Monde rural et agriculture, Atlas de Belgique, vol. 2. Gent: Academia Press.

Vanderheyden, Vincent; Van der Horst, Dan; Van Rompaey, Anton and Schmitz, Serge (2014). "Perceiving the ordinary: A study of everyday landscapes in Belgium”. Tijdschrift voor economische en sociale geografie, 105 (5), 591-603. <http://dx.doi.org/10.1111/tesg.12066>

Vidal-Naquet, Pierre (1992). "Genèse d'un haut lieu”. Méditerranée, 75 (1), 7-16. <http://dx.doi.org/10.3406/medit.1992.2749>

VlÈs, Vincent and HATT, Emeline (2015). Grand site Sainte Victoire: un haut lieu exemplaire? Impact des mesures de préservation dans les Grands sites naturels. Paris: Rapport de recherche PUCA.

Vos, Willem and KuIjn, Jan A. (2000). "Trends in European landscape development: Prospects for a sustainable future”. In: KLIJN, Jan A. and Vos, Willem (eds.). From Landscape Ecology to Landscape Science. Proceedings of the European Congress "Landscape Ecology: Things to Do-Proactive Thoughts for the 21st century". Dordrecht: Kluwer, 13-29.

Woods, Michael (2011). Rural. London: Routledge. 